\title{
Production Budget for Tomatoes in the Manatee-Ruskin Area of Florida 1
}

John VanSickle, Scott Smith, and Eugene McAvoy²

\section{Overview}

Tomatoes are an important crop to the state of Florida. Florida harvested 31,500 acres of tomatoes during the 2007-08 growing season, valued at over $\$ 622$ million dollars (Table 1). Acreage planted to tomatoes in Florida decreased 15 percent in 2008, and has decreased 28 percent since 2005 . While total value increased in 2008 by 46 percent, to $\$ 622$ million, it has decreased from its peak in 2005 by 22 percent. Yield per acre (25-pound cartons) averaged 1,418 cartons per acre from 2002-03 to 2007-08. Production peaked in 2004-05 at 62.1 million cartons, but decreased to 41.8 million cartons in 2007-08, a 32 percent decrease. Value per carton ranged from a low of \$7.98 in 2006-07 to a high of $\$ 14.88$ in 2007-08.

\section{Production Practices}

Production practices vary among Florida's tomato production areas. Most of the state's tomato crop is grown on polyethylene-mulched raised beds, using staked culture and drip or seep irrigation.

Fertilizer may be applied at planting under the plastic or a portion may be applied at planting, and the rest throughout the season with the drip irrigation system. Methyl bromide in combination with chloropicrin is applied to a majority of Florida's tomato acreage. Fumigants are injected into the soil during construction of the raised beds and are immediately covered with plastic mulch. Fumigants are applied for the management of soil insects, pathogens, nematodes, and weeds (especially nutsedge), all of which are major pests in tomato production. Tomato transplants are set in the mulched raised beds.

Standard spacing is approximately six feet between bed centers, with plants typically planted 18 to 30 inches apart. Wooden or metal stakes approximately four feet long are placed halfway between plants and driven into the beds for tying the plants. Pruning and tying provide vertical support. Tomatoes mature 90 to 110 days after transplanting. Tomatoes are typically harvested two to four times per season but potentially more often in profitable market conditions.

\section{Production Budgets}

Tables 2 and 3 are per-acre composite budgets for a representative grower in the Manatee-Ruskin area producing tomatoes for the 2007-08 fall and spring

1. This is EDIS document FE817, a publication of the Food and Resource Economics Department, Florida Cooperative Extension Service, Institute of Food and Agricultural Sciences, University of Florida, Gainesville, FL. Published December 2009. Please visit the EDIS website at http://edis.ifas.ufl.edu.

2. John VanSickle, professor, Food and Resource Economics Department, University of Florida, Gainesville, FL; Scott Smith, economic analyst, Food and Resource Economics Department, University of Florida, Gainesville, FL; and Eugene McAvoy, county extension director, Hardee County Extension, LaBelle, FL, Florida Cooperative Extension Service, Institute of Food and Agricultural Sciences, University of Florida, Gainesville, FL. 
seasons, respectively. The budgets break down the specific cost components used to estimate the budget expense categories and total estimated production costs per acre. The budgets are intended to reflect the cost of production using representative production practices that are considered typical for tomatoes grown in the Manatee-Ruskin area. What constitutes a representative production practice is defined by a consensus of opinion of UF/IFAS field experts, industry experts, and various producers in the tomato production area. Cost estimates resulting from this process do not represent the average cost of production in a statistical sense, and the practices listed are not necessarily recommended production practices. The intent of these cost budgets is to establish a benchmark within a comprehensive range of potential costs that could be expected to produce the crop. Tables 2 and 3 provide a Your Cost column so that you can enter your individual expenses for comparative purposes.

The production budgets for the 2007-08 fall and spring crops indicate that pre-harvest variable costs for a representative producer of fall tomatoes in the Manatee-Ruskin area totaled \$6,921 while pre-harvest variable costs for spring tomatoes totaled an estimated $\$ 6,589$ per acre. Fixed costs for a representative grower of a fall crop totaled an estimated $\$ 3,804$ per acre while fixed costs for the spring crop totaled $\$ 3,608$ per acre. With an assumed yield of 1,100 cartons per acre in the fall, harvest and marketing costs totaled $\$ 3,784$ per acre, bringing the total cost of production to an estimated $\$ 14,509$ per acre, or $\$ 13.19$ per carton. With an assumed yield of 1,550 cartons per acre for the spring crop, harvest and marketing costs totaled $\$ 5,332$ per acre, bringing the total cost of production to an estimated $\$ 15,529$ per acre, or $\$ 10.02$ per carton. The cost item that has increased most significantly since the 2005-06 budget is fertilizer, which increased 239 percent. Overall, operating costs, excluding the fertilizer expense, have increased a total of 12 percent since 2005-06.

\section{Additional Resources}

We have developed interactive workbooks containing the data used to create the UF/IFAS fall and spring tomato estimated budgets in Tables 2 and

3 . These workbooks can be used to produce cost estimates broken down by specific groups (e.g., herbicide). Included in these workbooks are pesticide worksheets listing all the currently labeled pesticides so that users can estimate their own pesticide costs, and machinery worksheets listing the machinery cost coefficients so that users can estimate their own fixed and variable costs. The International Agricultural Trade and Policy Center internet site (http://www.iatpc.ifas.ufl.edu) contains links to download these interactive Excel workbooks. These workbooks enable users to compare their production expenses to the UF/IFAS estimates presented in Tables 2 and 3 . These workbooks may be saved to your computer and printed in their entirety or printed as individual worksheets.

The following information is provided as a convenience to your research and decision making efforts.

- Botany: Family-Solanaceae, Tomato-Solanum esculentum

- Related Crops in the Solanaceae Family: Potato, Pepper, Eggplant, Tomatillo and Pepino.

- Common Tomato Varieties for Commercial Production:

- Large Fruited Varieties; Amelia, Bella Rosa, BHN-640, Crista, Crown Jewel, Flora-Lee, Florida 47, Florida 91, HA 3073, Linda, Phoenix, Quincy, RPT 6153, Sanibel, Sebring, Solar Fire, Salimar, Soraya, Talladega, Tygress.

- Plum Type Varieties; BHN 410. Midsesaon, BHN 411, BHN 685, Marianna, Monica, Plum Daddy, Spectrum 882 and Sunoma.

- Cherry Type Varieties; BHN 268, Camelia, Cherry Blossom, Mountain Belle, Shiren, Supper Sweet 100 VF.

- Grape Varieties; Brixmore, Cupid, Jolly Elf, Santa, St Nick, Smarty and Tami G.

For further information on tomato production in Florida please refer to EDIS publication HS739 (http://edis.ifas.ufl.edu/CV137) or contact your local 
extension specialists.

\section{References}

Olson, S.M., W.M. Stall, M.T. Momol, S.E.

Webb, T.G. Taylor, S.A. Smith and E.H. Simone.

2007. Chapter 41, Tomato Production in Florida. In

Vegetable Production Handbook for Florida

2006-2007. Electronic Data Information Source EDIS

document HS739. Horticultural Science Department, University of Florida, Gainesville, FL.

http://edis.ifas.ufl.edu/CV137

USDA/NASS. 2009. Crop Statistics. United States Department of Agriculture, National

Agricultural Statistics Service, Washington, D.C.

http://quickstats.nass.usda.gov/ 
Production Budget for Tomatoes in the Manatee-Ruskin Area of Florida

Table 1. Florida tomatoes acreage, fresh market production, and value, crop years, 2002-03 through 2007-08.

\begin{tabular}{|c|c|c|c|c|c|c|}
\hline \multirow[t]{2}{*}{ Season } & Planted & Harvested & Yield & Production & Unit Value & Total Value \\
\hline & (acres) & (acres) & (25-lb bushels) & ( 1,000 bushels) & (dollars) & (1,000 dollars) \\
\hline 2002-03 & 43,300 & 43,000 & 1,320 & 56,760 & 9.70 & 550,572 \\
\hline 2003-04 & 42,400 & 42,000 & 1,440 & 60,480 & 8.28 & 500,472 \\
\hline 2004-05 & 45,200 & 42,000 & 1,480 & 62,160 & 12.95 & 804,972 \\
\hline 2005-06 & 41,200 & 38,500 & 1,400 & 53,900 & 10.23 & 551,128 \\
\hline 2006-07 & 38,200 & 37,800 & 1,540 & 58,212 & 7.98 & 464,241 \\
\hline 2007-08 & 32,400 & 31,500 & 1,328 & 41,832 & 14.88 & 622,251 \\
\hline
\end{tabular}

Table 2. Estimated costs of producing one acre of tomatoes in the Manatee-Ruskin area, fall 2007.

\begin{tabular}{|c|c|c|c|c|c|}
\hline \multirow[t]{2}{*}{ Based on Yield of 1,100 Units Per Acre } & Unit & Quantity & Price & Value & Your Cost \\
\hline & & & (dollars) & (dollars) & \\
\hline \multicolumn{6}{|l|}{ Pre-Harvest Variable Costs } \\
\hline Transplants & & & & 416.00 & \\
\hline Fertilizer, mixed and lime & & & & $1,448.40$ & \\
\hline Fumigant & & & & 675.00 & \\
\hline Herbicide & & & & 45.35 & \\
\hline Insecticide & & & & 635.94 & \\
\hline Fungicide & & & & 410.31 & \\
\hline Tractor + machinery & & & & $1,216.89$ & \\
\hline Truck (pickup) & & & & 33.34 & \\
\hline Labor & & & & 635.37 & \\
\hline Plastic mulch & & & & 330.00 & \\
\hline Scouting & & & & 35.00 & \\
\hline Stakes & & & & 112.00 & \\
\hline Cut/pull/bundle mulch & & & & 125.00 & \\
\hline Plastic string & & & & 100.00 & \\
\hline Tie plants & & & & 145.20 & \\
\hline String and stake disposal & & & & 217.80 & \\
\hline Interest on operating capital (10\%) & & & & 339.37 & \\
\hline Total Pre-Harvest Variable Costs & & & & $6,920.97$ & \\
\hline
\end{tabular}


Table 2. Estimated costs of producing one acre of tomatoes in the Manatee-Ruskin area, fall 2007.

\begin{tabular}{|c|c|c|c|c|c|}
\hline \multirow[t]{2}{*}{ Based on Yield of 1,100 Units Per Acre } & Unit & Quantity & Price & Value & Your Cost \\
\hline & & & (dollars) & (dollars) & \\
\hline \multicolumn{6}{|l|}{ Pre-Harvest Fixed Costs } \\
\hline Tractor + machinery & & & & 281.08 & \\
\hline Land rent & & & & 300.00 & \\
\hline Overhead and management & & & & $3,223.21$ & \\
\hline Total Pre-Harvest Fixed Costs & & & & $3,804.29$ & \\
\hline Total Pre-Harvest Costs & & & & $10,725.26$ & \\
\hline \multicolumn{6}{|l|}{ Harvest and Marketing Costs } \\
\hline Pick/pack/haul & carton & 1,100 & 2.45 & $2,695.00$ & \\
\hline Sell & carton & 1,100 & 0.15 & 165.00 & \\
\hline Containers & carton & 1,100 & 0.75 & 825.00 & \\
\hline Organization fees & carton & 1,100 & 0.09 & 99.00 & \\
\hline Total Harvest and Marketing Costs & & & & $3,784.00$ & \\
\hline Total Costs & & & & $14,509.26$ & \\
\hline
\end{tabular}

Table 3. Estimated costs of producing one acre of tomatoes in the Manatee-Ruskin area, spring 2008.

\begin{tabular}{|c|c|c|c|c|c|}
\hline \multirow[t]{2}{*}{ Based on Yield of 1,550 Units Per Acre } & Unit & \multirow[t]{2}{*}{ Quantity } & \multirow{2}{*}{$\frac{\text { Price }}{\text { (dollars) }}$} & Value & \multirow[t]{2}{*}{ Your Cost } \\
\hline & & & & (dollars) & \\
\hline \multicolumn{6}{|l|}{ Pre-Harvest Variable Costs } \\
\hline Transplants & & & & 585.00 & \\
\hline Fertilizer, mixed and lime & & & & $1,448.40$ & \\
\hline Fumigant & & & & 675.00 & \\
\hline Herbicide & & & & 45.35 & \\
\hline Insecticide & & & & 520.17 & \\
\hline Fungicide & & & & 264.45 & \\
\hline Tractor + machinery & & & & $1,095.28$ & \\
\hline Truck (pickup) & & & & 33.34 & \\
\hline Labor & & & & 560.39 & \\
\hline Plastic mulch & & & & 330.00 & \\
\hline
\end{tabular}


Table 3. Estimated costs of producing one acre of tomatoes in the Manatee-Ruskin area, spring 2008.

\begin{tabular}{|c|c|c|c|c|c|}
\hline \multirow[t]{2}{*}{ Based on Yield of 1,550 Units Per Acre } & Unit & Quantity & Price & Value & Your Cost \\
\hline & & & (dollars) & (dollars) & \\
\hline Scouting & & & & 35.00 & \\
\hline Stakes & & & & 112.00 & \\
\hline Cut/pull/bundle mulch & & & & 125.00 & \\
\hline Plastic string & & & & 100.00 & \\
\hline Tie plants & & & & 145.20 & \\
\hline String and stake disposal & & & & 217.80 & \\
\hline Interest on operating capital (10\%) & & & & 296.21 & \\
\hline Total Pre-Harvest Variable Costs & & & & $6,588.59$ & \\
\hline \multicolumn{6}{|l|}{ Pre-Harvest Fixed Costs } \\
\hline Tractor + machinery & & & & 235.94 & \\
\hline Land rent & & & & 300.00 & \\
\hline Overhead and management & & & & $3,072.74$ & \\
\hline Total Pre-Harvest Fixed Costs & & & & $3,608.68$ & \\
\hline Total Pre-Harvest Costs & & & & $10,197.27$ & \\
\hline \multicolumn{6}{|l|}{ Harvest and Marketing Costs } \\
\hline Pick/pack/haul & carton & 1,550 & 2.45 & $3,797.50$ & \\
\hline Sell & carton & 1,550 & 0.15 & 232.50 & \\
\hline Containers & carton & 1,550 & 0.75 & $1,162.50$ & \\
\hline Organization fees & carton & 1,550 & 0.09 & 139.50 & \\
\hline Total Harvest and Marketing Costs & & & & $5,332.00$ & \\
\hline Total Costs & & & & $15,529.27$ & \\
\hline
\end{tabular}

